\title{
Adult Cerebellar Neoplasm
}

National Cancer Institute

\section{Source}

National Cancer Institute. Adult Cerebellar Neoplasm. NCI Thesaurus. Code C5968.

A benign or malignant, primary or metastatic neoplasm of the cerebellum occurring in adults. 